\title{
Water footprint for industrial products. A paradigm of concentration
}

\author{
R M Gogonea ${ }^{1}$ \\ ${ }^{1}$ Statistics Departament, Academy of Economic Studies , București, Ramânia \\ manuela.gogonea@gmail.com
}

\begin{abstract}
Linking economic research to the sustainability process also includes the need to study water footprint issues of consumption of industrial products. In this context, the water footprint of the consumption of industrial products from the point of view of the territorial concentration in European countries is analyzed. At the same time, this type of water is approached on the two categories of components: blue and gray, taking into account the volume of water resources used internally and externally for the production of goods and services consumed by the population. Also, the degree of concentration of water footprint of the consumption of industrial products was determined in the paper. Thus, two of the most significant indicators (Gini Coefficient and Shannon Entropy) were used and relevant concentration curves were constructed. The results highlighted for both categories, blue and gray, a high degree of internal concentration and reduced external focus. Taking into account the results the future orientation is to develop and implement environmental strategies that will reduce the water footprint of the consumption of industrial products, especially for the internal category.
\end{abstract}

Keywords: water footprint of consumption, industrial products, concentrare, blue și grey, internal și external.

\section{Introduction}

Under the conditions of sustainable development, the accelerated population growth, and the limited use of resources, the issue of water use becomes a top priority. It is estimated that by 2025 about onethird of the world's population will live in water-stressing countries [1].

Incorrect water management becomes a complex problem with a significant impact on its availability. At the same time, climate change is on the one hand on water systems, on the one hand, and on global water cycling. This context favors modifying the ways of addressing the current development model towards a new model with a priority approach to exploiting resources without taking into account the future [2].

It is increasingly evident that ideological approaches and economic or political agendas need to have sustainable development approaches to treat pragmatically water management and water macroeconomics, as life on the planet depends on the success of efficient water resource management[3]. The interest in the sustainable use of water is rapidly increasing both in civil society and in business communities, but the poor transparency of companies with regard to direct and indirect water use is still a significant impediment. [4]

In order to reduce the internal water footprint to produce a particular product, the report Reducing our water footprint [5] proposes three steps. 
A first step is to identify the basic footprint for the production of semi-finished products, which in the second step contends with the estimation of the water footprint used in the production of the final product.

Finally, the third step, and perhaps most importantly, is to identify ways to reduce water consumption by quantifying and mapping the water footprint needed to produce a particular product and identifying the site where efficient water use can be assisted and reducing the negative impact of product production.

Water footprint issues are also covered by the article The water footprint of humanity [6]. It quantifies and analyzes the distribution of water footprint for industrial products in the countries of the European Union. It analyzes the use of surface water (bluewater footprint) and volumes of ground water (gray water footprint) at country level as well as at EU level. Both the use of internal and external water resources are analyzed. The latter being the international streams of virtual water in corporations in industrial products involved in import - export processes.

Starting from these aspects, this paper analyzes the distribution of water footprints for the production of industrial products, highlighting both its internal and external components. It is structured in four parts. After the introductory part the paper includes the methodology applied in the analysis of the territorial concentration of the water footprint of the consumption of industrial products.

The third chapter consists of two subchapters in which the outcomes aspects and discussions on the internal water footprint of the consumption of industrial products and the external water footprint of the consumption of industrial products are presented and analyzed. The conclusions highlight both the similarities between EU countries regarding the water footprint for industrial products and the differences between them (significant concentrations of the internal component).

\section{Research methodology}

Water footprint is the amount of water consumed (evaporated or incorporated in a product) or polluted per unit of time. A schematic representation of Total water footprint of national consumption is shown in Figure 1.

The water footprint of national consumption (WFN) is calculated as the sum of the direct water footprint of the nation-wide consumer $\left(\mathrm{WF}_{\mathrm{dir}}\right)$, and two of its indirect components [7], corresponding to the import of agricultural products $\left(\mathrm{WF}_{\text {indir.agr }}\right)$ and industrial products $\left(\mathrm{WF}_{\text {indir.ind }}\right)$ for domestic consumption:

$$
W F=W F_{\text {cons.dir }}+W F_{\text {indir.agr }}+W F_{\text {indir.ind }}
$$

The components $\mathrm{WF}_{\text {indir.agr }}$ and $\mathrm{WF}_{\text {indir.agr }}$ represent the amount of water consumed (used) by other countries for the production of agricultural and industrial products imported by that country and consumed by the consumers of the analyzed nation. This method of calculation is a bottom-up approach.

In the top-down approach, the water footprint of national consumption is calculated taking into account water footprint within the nation (WFN), virtual-water import (VWI) and virtual-water export (VWE).

$$
W F=W F N+V W I-V W E
$$

Another approach to water footprint determination takes into account the two components (internal and external), both targeting both the use of blue water and the use of green water:

$$
W F=A W U+I W W+D W W-V W E_{d o m}
$$

In (3), AWU is the use of water in agriculture, equal to the water required by evaporation of crops (including effective rainfall, irrigation water, not including irrigation losses during water use in agriculture), IWW is water withdrawals in the industrial sector, DWW is household water withdrawals, and $\mathrm{VWE}_{\mathrm{dom}}$ is the export of virtual water to other countries (if they are related to the export of domestically produced products). 


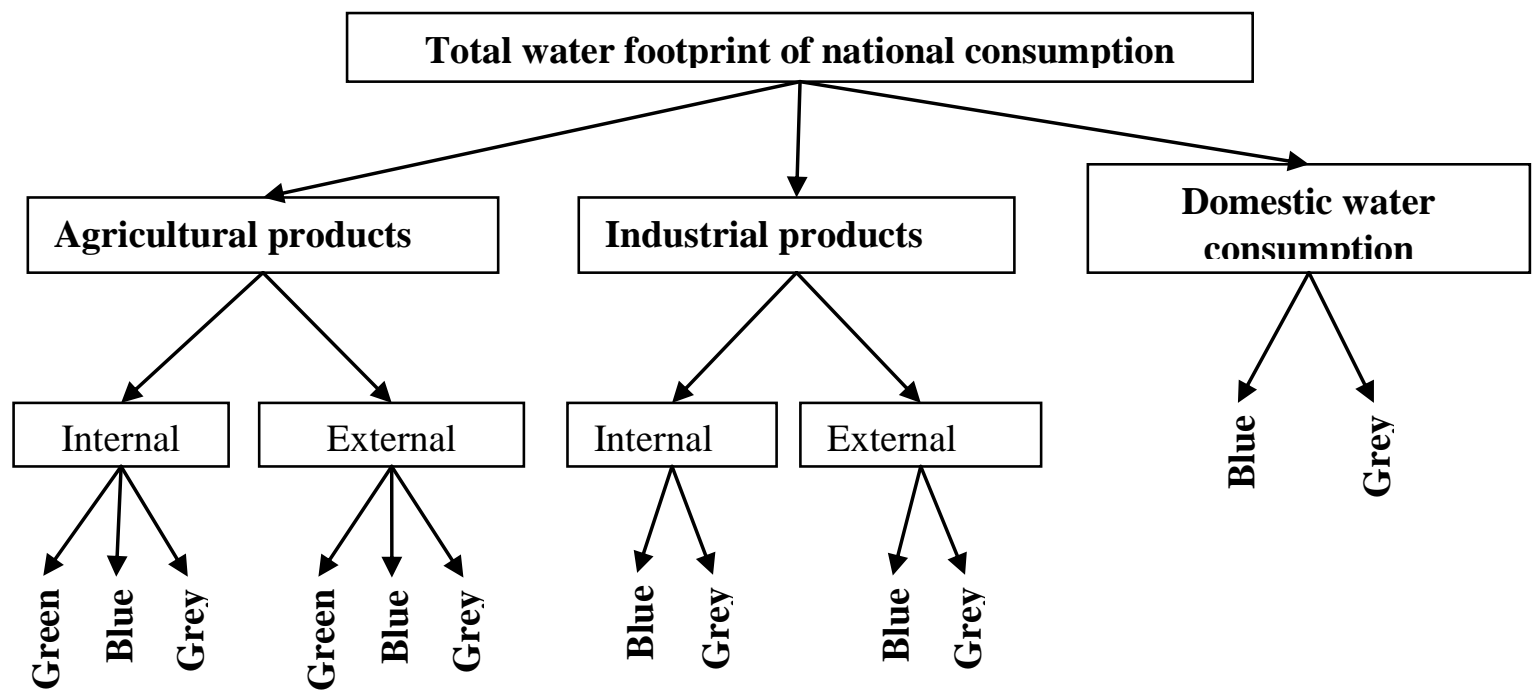

Figure 1.The structure of Total water footprint of national consumption in EU countries, shown by major consumption category and by internal and external component

Starting from the ways of determining the water footprint of national consumption, and based on the series of data provided by [7], the degrees of concentration of water footprint of industrial products in the EU countries were analyzed both in terms of the two components, internal both external and on both water categories blue and grey.

For the degree of concentration analysis, both graphical (Concentration Curve) and numerical indicators [8], including Gini Coefficient (GC) and Shannon Entropy (SE), were used:

$$
\begin{aligned}
& G C=\sqrt{\sum_{i=1}^{n} g_{i}^{2}}, \quad g_{i}=\frac{x_{i}}{\sum_{i=1}^{n} x_{i}}, \quad G C \in\left[\sqrt{\frac{1}{n}}, 1\right] \\
& S E=\sum_{i=1}^{n} g_{i} \cdot \ln \frac{1}{g_{i}}, \quad S E \in[1, \ln n]
\end{aligned}
$$

In relation (4), $X$ represents the water footprint weight of each territorial unit in the cumulated value, calculated at the level of the $28 \mathrm{EU}$ countries. Under these conditions $G C \in[0.189,1]$ and $S E \in[1,3.332]$ the concentration being even higher as the $\mathrm{GC}$ values are closer to the maximum value range (1.0) and SE closer to the minimum range (1.0).

In order to facilitate the analysis, the intervals of variation of the four categories of indicators analyzed were divided into six equal intervals. These ranges allowed grouping and cluster analysis of the water footprint in the analyzed countries.

\section{Results and discussion}

Water footprint of consumption of industrial products, as shown in Figure 1, and as presented above, consists of two components: internal and external. Taking this into account, the analysis was carried out in these two directions. 


\subsection{Internal water footprint of consumption of industrial products}

The use of blue domestic water resources to produce goods and services in the industry, consumed by the nation's population, is experiencing a concentrated concentration process in EU countries (Figure 2). This feature is also highlighted by GC (0.45) and SE (2.987) values.

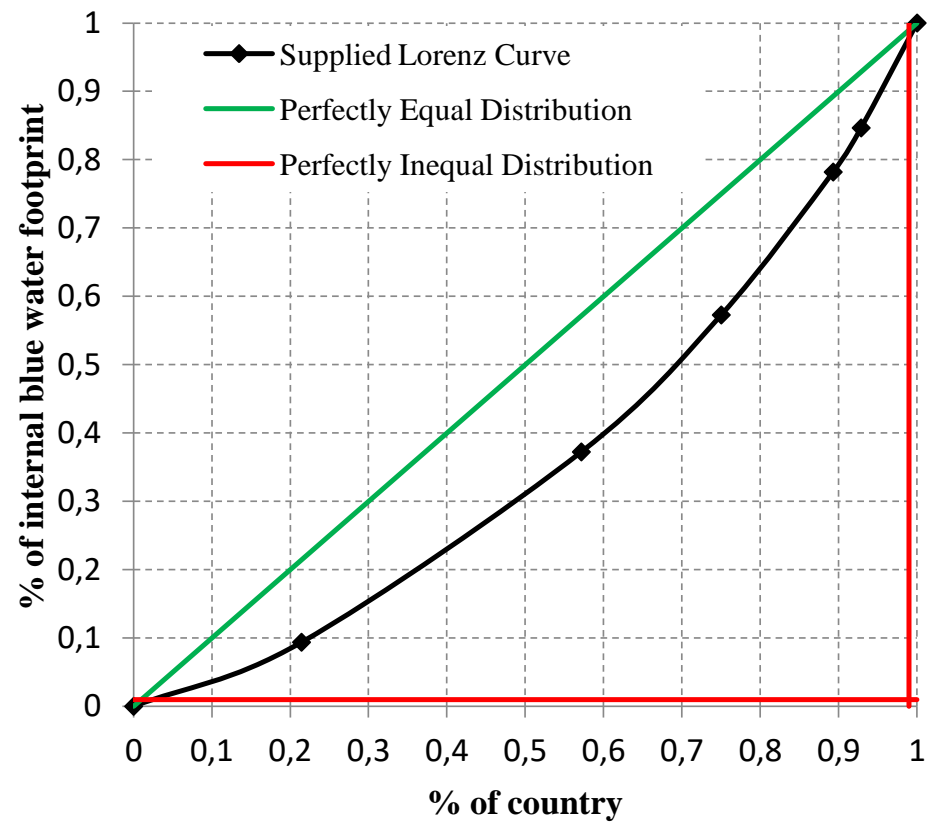

Figure 2. The concentration curve of the internal blue water footprint of consumption per capita, for industrial products

The highest concentration of countries is recorded in the first two groups (Table 1), for which the average water consumption per capita of industrial products is quite small, ranging from 0.03 to 4.94 $\mathrm{m}^{3} / \mathrm{yr} / \mathrm{cap}$, which means that these countries do not consume much blue water for industrial products.

Table 1. Grouping of EU countries according tointernal blue water footprint of consumption per capita for industrial products

\begin{tabular}{|c|l|c|}
\hline Cluster & \multicolumn{1}{|c|}{ Countries } & $\begin{array}{c}\text { Intervale variaţie } \\
\text { (m3/yr/cap) }\end{array}$ \\
\hline 1 & $\begin{array}{l}\text { Malta, Cyprus, Lithuania, Croatia, Greece, Estonia, Luxembourg, } \\
\text { Latvia, Denmark }\end{array}$ & $0.03-2.48$ \\
\hline 2 & Slovakia, Ireland, Czech Republic, UK, Portugal, Sweden & $2.48-4.94$ \\
\hline 3 & Austria, Spain, Netherlands & $4.94-7.39$ \\
\hline 4 & Ramania, Italy, Slovenia & $7.39-9.84$ \\
\hline 5 & Germany, Finland, Hungary, poland & $9.84-12.29$ \\
\hline 6 & Bulgaria, Belgium, France & $12.29-14.74$ \\
\hline
\end{tabular}

The countries of the first group account for $32.14 \%$ of the total of the 28 EU countries and account for only $6.95 \%$ of the total blue water footprint of consumption per capita of industrial products. It is noteworthy that it is the group with most countries that have a fairly small amount of blue water footprint of between 0.03 and $2.48 \mathrm{~m}^{3} / \mathrm{yr} /$ cap.

In the second group, the consumption of internal blue water footprint of consumption per capita of industrial products is between 2.48 and $4.94 \mathrm{~m} 3 / \mathrm{yr} / \mathrm{cap}$. This is added to those in the first group, accounting for $53.57 \%$ of all countries. In this context, for all these countries, the average internal blue water consumption per capita of industrial products will represent $20.63 \%$ of the total. 
The following four groups of countries were fairly balanced allocation as regards internal consumption of blue internal wather industrial products (three or four countries per group).

Environmental conditions, together with other specific factors, allow three other countries (Austria, Spain, Netherlands) to reach internal blue wather consumption of industrial products between 4.94 and $7.39 \mathrm{~m}^{3} / \mathrm{yr} / \mathrm{cap}$, so that for $64.29 \%$ of the total countries to match an internal blue water footprint of $31.99 \%$ per capita industrial products. A share of $47.87 \%$ of the total water consumption per capita of industrial products belongs to $75 \%$ of all EU countries (for the 18 countries three countries have been added: Romania, Italy, Slovenia) for which consumption is between 7.39-9.84 $\mathrm{m}^{3} / \mathrm{yr} / \mathrm{cap}$. Germany, Finland, Hungary, Poland together with the other 21 countries ( $89.29 \%$ of the total countries) will hold $75.08 \%$ of the total blue water footprint of consumption per capita of industrial products.

The largest domestic water users of industrial products are Bulgaria, Belgium, France, the quantities being between 12.29-14.74 m3 / yr / cap. For these countries, there are deficiencies in the use of inefficient water technology and adequate water prices.

With regard to the internal gray water footprint of the consumption per capita of industrial products (Figure 3), it is highlighted that in a large part of the EU countries the variation of the internal gray water footprint of the consumption of industrial products has low values, sustainable development point of view. We also assume here a concentration process highlighted by both the graphical representation of the Lorentz curve and the GC (0.494) and SE (2.631) values.

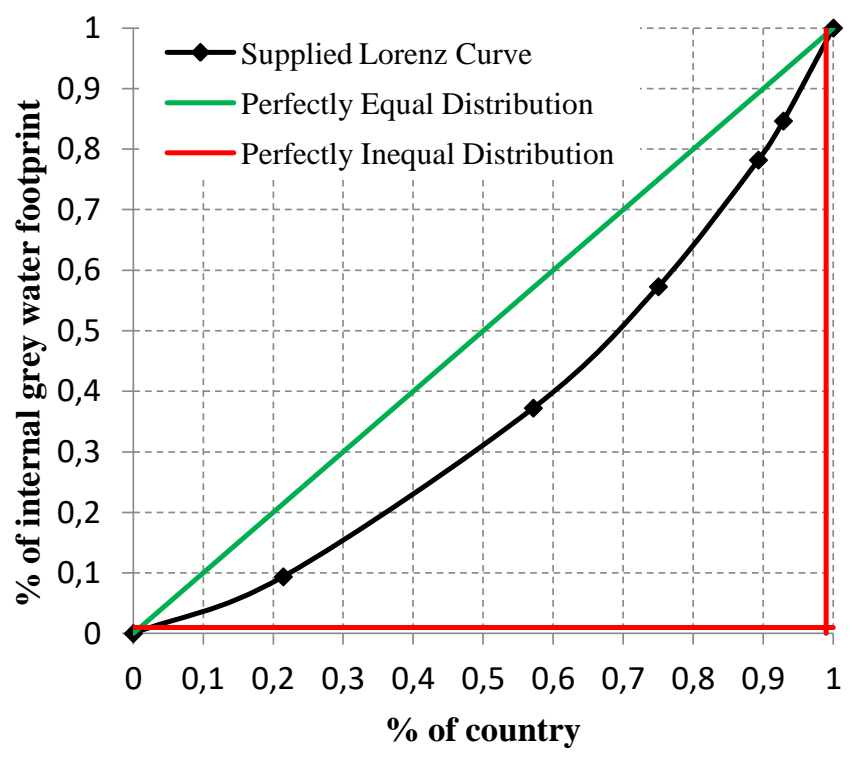

Figure 3. Concentration curve of the internal grey water footprint of consumption of industrial products

Thus, in the first cluster (Table 2) with values of internal gray water footprint of consumption of industrial products ranging from 0.00 to $23.27 \mathrm{~m} 3$ / yr / cap, there are 18 countries. Under these circumstances, $64.29 \%$ of the EU countries produce only $23.68 \%$ of the total internal grey water footprint of consumption by internal of industrial products. Portugal and Finland, two compartments of the second group, record a higher water footprint of $23.27-46.54 \mathrm{~m}^{3} / \mathrm{yr} / \mathrm{cap}$, the percentage of gray water footprint of consumption by domestic industrial products in total to $31.58 \%$.

As we move to another cluster, the range of variation increases by $23.27 \mathrm{~m}^{3} / \mathrm{yr} / \mathrm{cap}$. In this way, Italy, France and Hungary, which are at the middle of the group's ranking, will contribute their water footprint to a share of $43.42 \%$ in the total of gray industrial footprint of consumption.

The following two groups include two component countries (Slovenia and Poland, respectively Romania and Belgium). They need to adopt, and apply, more drastic measures to address the issue of 
Volume 1, Issue 1, 2019

ISSN: 2668-0416

Thoth Publishing House

pollution, in order to reduce the value of internal grey water footprint of consumption of industrial products.

Table 2. Distribution of countries by groups after the internal gray water footprint of consumption per capita of industrial products

\begin{tabular}{|c|c|c|}
\hline Cluster & Countries & $\begin{array}{c}\text { Intervale variație } \\
\text { (m3/yr/cap) }\end{array}$ \\
\hline 1 & $\begin{array}{l}\text { Spain, Malta, Netherlands, Luxemburg, Lithuania, UK, Cyprus, } \\
\text { Greece, Estonia, Denmark, Croatia, Austria, Latvia, Germany, } \\
\text { Ireleand, Sweden, Czech Republic, Slovenia }\end{array}$ & $0.00-23.27$ \\
\hline 2 & Portugal, Finland & $23.27-46.54$ \\
\hline 3 & Italy, France, Hungary & $46.54-69.81$ \\
\hline 4 & Slovenia, Poland & $69.81-93.08$ \\
\hline 5 & Ramania, Belgium & $93.08-116.35$ \\
\hline 6 & Bulgaria & $116.35-139.62$ \\
\hline
\end{tabular}

The country with the most acute problem of water pollution is Bulgaria, which, by $139.6 \mathrm{~m}^{3} / \mathrm{yr} / \mathrm{cap}$, occupies the last place in the ranking and creates a big gap with the other 18 countries with a maximum of $23.27 \mathrm{~m}^{3} / \mathrm{yr} / \mathrm{gray}$ water footprint of consumption of industrial products.

3.2. External water footprint of consumption of industrial products

The external component highlights the amount of water per inhabitant arriving in a country, embedded in the volume of indigenous imported products. Its concentration channels can provide information on the intensity of import flows in those countries.

The analysis of the concentration of the external blue water footprint of the consumption of industrial products shows that in this case the degree of concentration is low, aiming at uniformity. This fact is highlighted on the one hand by the Lorentz curve (Figure 4) as well as the GC and SE values. Thus GC has a value of 0.28 , much lower than the internal blue water footprint of industrial products, and the SE value is 3.20, significantly higher than for both types of internal water footprint of consumption of industrial products.

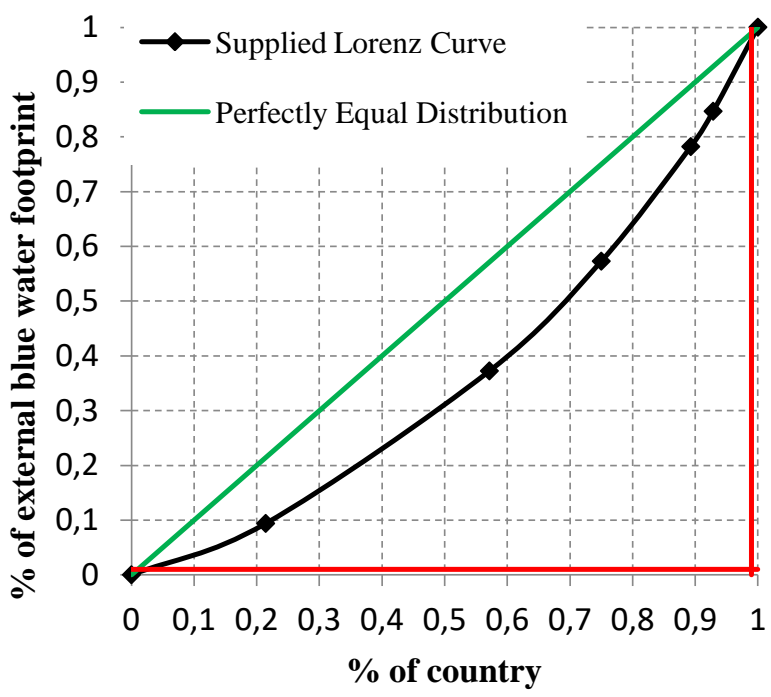

Figure 4 - Concentration curve of the external blue water footprint of consumption per capita of industrial products 
However, there are two Belgium and Luxembourg countries (Table 3) that differ significantly from the other 26 countries where the external water consumption of industrial products is much higher than in other countries. Thus, compared to Austria, the third ranked in terms of the external blue water footprint of industrial consumption, Luxembourg $\left(28.2978 \mathrm{~m}^{3} / \mathrm{yr} / \mathrm{cap}\right)$ is 1.54 times higher and in Belgium (27.8860 $\left.\mathrm{m}^{3} / \mathrm{yr} / \mathrm{cap}\right), 1.52$ times higher. As a consequence of this particular situation in the range of $19.64 \mathrm{~m}^{3} / \mathrm{yr} / \mathrm{cap}-23.96 \mathrm{~m}^{3} / \mathrm{yr} / \mathrm{cap}$, no country is included. As a result, the grouping of countries presented in Table 3 comprises only 5 clusters.

Table 3. Distribution of countries by groups after variation of the internal grey water footprint of consumption per capita of industrial products

\begin{tabular}{|c|l|c|}
\hline Cluster & \multicolumn{1}{|c|}{ Countries } & $\begin{array}{c}\text { Variation intervals } \\
\text { (m3/yr/cap) }\end{array}$ \\
\hline 1 & Bulgaria, România, Polonia, Portugal, Hungary & $2.30-6.66$ \\
\hline 2 & $\begin{array}{l}\text { Slovenia, Croația, Ireland, Czech Republic, Italy, Estonia, Spain, } \\
\text { France, Malta, Germany, Sweden }\end{array}$ & $6.66-10.98$ \\
\hline 3 & Greece, Slovenia, UK, Cyprus, Finland & $10.98-15.31$ \\
\hline 4 & Denmark, Latvia, Netherlands, Austria & $15.31-19.64$ \\
\hline 5 & Belgium, Luxemburg & $23.96-28.29$ \\
\hline
\end{tabular}

The second component of the external water footprint of the consumption of industrial products is gray water. Characteristically, at EU level, the degree of concentration is the lowest. The GC value of 0.267 is the lowest of all GC values recorded in the analysis performed, and the SE value of 3.213 is the highest.

On the other hand, the Lorentz curve (Figure 5) highlights this finding, basically pointing to the lack of concentration in the case of external grey footprint of consumption per capita of industrial products.

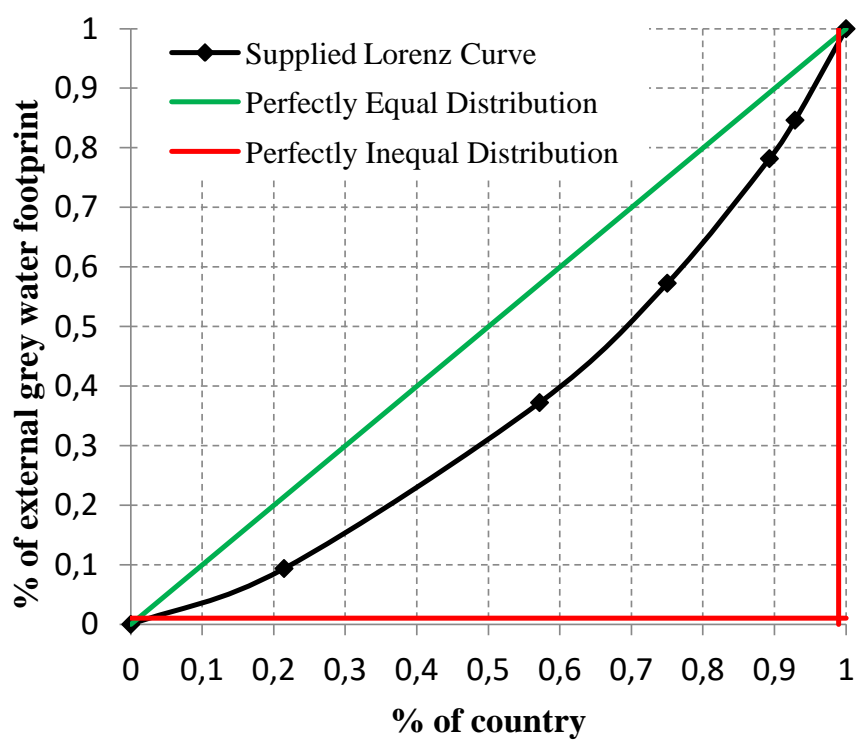

Figure 5 - Concentration curve of the external grey water footprint of consumption per capita of industrial products

As in the case of the external blue water footprint of consumption of industrial products, besides Belgia and Luxembourg (Table 4) there is another country (Latvia) where the external blue water footprint of consumption per capita of industrial products is significantly higher than in the other 25 EU countries. Also in this case, compared to Austria, the fourth ranked in terms of external gray water 
footprint of consumption per capita of industrial product, in Belgium $\left(283.4 \mathrm{~m}^{3} / \mathrm{yr} / \mathrm{cap}\right)$ there is a value of 1.48 times higher, in Luxembourg $\left(272.2 \mathrm{~m}^{3} / \mathrm{yr} / \mathrm{cap}\right), 1.43$ times higher, and in Latvia $(231.5$ $\left.\mathrm{m}^{3} / \mathrm{yr} / \mathrm{cap}\right), 1.22$ times higher

Table 4. Distribution of countries by groups after variation of the internal grey water footprint of consumption per capita of industrial products

\begin{tabular}{|c|l|c|}
\hline Cluster & \multicolumn{1}{|c|}{ Countries } & $\begin{array}{c}\text { Intervale variatie } \\
\text { (m3/yr/cap) }\end{array}$ \\
\hline 1 & Bulgaria, Romania, Portugal, Poland, Slovakia, Hungary & $32.5-74.35$ \\
\hline 2 & $\begin{array}{l}\text { Czech Republic, Italy, Croatia, Spain, Estonia, France, Ireland, } \\
\text { Lithuania, Germany, Malta }\end{array}$ & $74.35-116.15$ \\
\hline 3 & Slovenia, Sweden, UK, Greece, Finland, & $116.15-157.95$ \\
\hline 4 & Denmark, Cyprus, Netherlands, Austria & $157.95-199.75$ \\
\hline 5 & Latvia & $199.75-241.55$ \\
\hline 6 & Luxembourg, Belgium & $241.55-283.36$ \\
\hline
\end{tabular}

\section{Conclusions}

The study was developed taking into account, on the one hand, the blue and gray water categories and on the other hand the components that include the water resources needed for the production of goods and services consumed by the population, which is used internally and externally.

The process of pooling water consumption data across European countries has been used as the first step in determining the degree of concentration of water footprint of the consumption of industrial products. The second step included the calculation of the most significant indicators (Gini Coefficient and Shannon Entropy) through which the low concentration of the internal and external category for both types (blue and gray) was highlighted. These results were also confirmed by graphical representation of the concentration curves. In this situation, it is necessary to develop strategies that guide the environmental policies in the direction of reducing the water footprint of the consumption of industrial products, having priority with the internal category. The results show that the pattern of trade at international level significantly influences water consumption in most European countries. Against this background, it is recommended that country-specific water policy studies be prepared to include the assessment of trade effects on water policy.

\section{References}

[1] Pryor F. L. 2007 Water stress and water wars. Economics of Peace and Security Journal, vol. 2, no. 2, pp. 7-18.

[2] Chebly J. E. 2014 The Value of Water: Economics of Water for a Sustainable Use. The Economic and Social Review, vol. 45, no. 2, pp. 207 - 222.

[3] Dalhuisen J, Groat H, Nijkamp P. 1999 The economics of water: a survey of issues, Serie Research Memoranda from VU University Amsterdam.

[4] Hoekstra A.Y., Ghapagain A.K., Zhang G. 2015 Water Footprints and Sustainable Water Allocation. vol. 8, no. 1, pp. 1-6.

[5] IWMI 2009 Reducing our water footprint, Water Figures: quarterly newsletter of the International Water Management Institute. International Water Management Institute

[6] Mekonnen M.M., Hoekstra A.Y., Mesfin M. 2011 The water footprint of humanity. Pacific Institute for Studies in Development, Environment, and Security, Oakland.

[7] Mekonnen, M.M.; Hoekstra, A.Y. 2011 National water footprint accounts: The green, blue and grey water footprint of production and consumption. Value of Water Research Report Series No. 50, UNESCO-IHE, Delft, Netherlands.

[8] Jaba E. 2002 Statistică, Editura Economică, Bucuresti. 